\title{
Escapable/inescapable pretraining and subsequent avoidance performance in human subjects*
}

\author{
RICHARD L. WILLIAMS and GENE H. MOFFAT $\dagger$ \\ University of Southern Mississippi, Hattiesburg, Mississippi 39401
}

\begin{abstract}
Seventy-two Ss were tested in an escape/avoidance task in which omission of entertaining material served as the aversive stimulus event. Prior to these trials, Ss received 0, 15, or 30 escapable trials and either 0 or 100 inescapable trials with the same aversive stimulus. The results indicated that inescapable trials interfered with performance on the escape/avoidance task and that escapable trials negated the interference effect. The pretraining conditions more directly affected escape rather than avoidance performance.
\end{abstract}

The effects of prior inescapable aversive stimulation on subsequent escape/avoidance behavior in infrahuman Ss have been documented recently (e.g., Seligman, Maier, \& Solomon, 1971). Reference experiments (e.g., Seligman \& Maier, 1967) have reported that prior inescapable shock interferes with the subsequent acquisition of escape/avoidance responses. Seligman et al (1971) labeled this paradigm "learned helplessness" and argued that it is not shock per se which produces this failure to respond, but rather the fact that infrahuman Ss learn that they have no control over the occurrence or nonoccurrence of shock. The acquisition of this independent relationship between Ss' response patterns and shock termination results in helplessness.

Seligman and Maier (1967) tested the hypothesis that experience with controllable shock would prevent the interference effect of the uncontrollable shock on subsequent escape/avoidance task. They gave dogs 10 shuttlebox escape/avoidance trials before administering inescapable shock trials in a harness situation. Following inescapable shock, Ss were presented additional escape/avoidance trials. On these trials, Ss successfully escaped and avoided shock. Interference was shown, however, in Ss not receiving controllable shock in the shuttlebox. Seligman and Maier (1967) argued that Ss' control over shock on the initial shuttlebox trials immunized Ss against the interference effect resulting from uncontrollable shock. Thus, the effect of uncontrollable shock depends partially on the degree of control Ss have acquired prior to being subjected to the uncontrollable shock (Seligman et al, 1971).

Investigations of the learned helplessness paradigm with human Ss have been quite limited. Thornton and Jacobs (1971) found general support for learning helplessness in college Ss using variable levels of shock

\footnotetext{
* Research supported in part by USM Faculty Grant (No. 2576).

+Article based on a thesis submitted to the Graduate School of the University of Southern Mississippi by the first author in partial fulfillment of the requirements for the MA degree. Reprint requests should be sent to the second author Department of Psychology, University of Southern Mississippi, Hattiesburg, Mississippi 39401.
}

(0.5 to $2.5 \mathrm{~mA})$. In terms of Ss' reaction time scores, the performance of Ss receiving inescapable pretraining decreased significantly on the test trials. The performance of Ss in the avoidable pretraining group increased significantly across the test trials. However, the performance of control Ss not receiving shock while performing the training task did not differ significantly from Ss receiving inescapable shock. They attributed their equivocal results to the effects of instructions which varied across groups.

The present experiment was designed also to investigate the effects of inescapable and escapable exposure to an aversive stimulus event and subsequent escape/avoidance performance in adult human Ss. Unlike previous experiments which employed shock, omission of entertaining material constituted the aversive stimulus event. Koch and Moffat (1974) demonstrated the functional equivalence between the onset of a noxious stimulus and omission of entertaining material in a discrete-trial avoidance conditioning task. College Ss received either a 98- or a $120-\mathrm{dB}$ tone or a $5-\mathrm{sec}$ omission of Bill Cosby recording for failure to avoid. The only significant difference between groups was obtained from the analysis of the avoidance response latencies. While latencies for Ss in the Bill Cosby group were significantly slower than the latencies of Ss in the 120-dB group, their latencies were significantly faster than the latencies of Ss in the 98-dB group.

Three levels of escapable pretraining and two levels of inescapable trials were presented to Ss utilizing a 3 by 2 factorial design prior to the escape/avoidance trials. It was predicted that increased levels of escape pretraining would facilitate subsequent escape/avoidance performance while increased levels of inescapable trials would inhibit performance.

\section{METHOD}

\section{Subjects}

Ss were 72 undergraduate students enrolled in psychology classes at the University of Southern Mississippi. 


\section{Apparatus}

The apparatus has been described in detail elsewhere (Koch \& Moffat, 1974). Briefly, the apparatus consisted of a response box with a light mounted on it, timers and interconnecting circuitry to control events, a modified tape recorder and headphones, and taped selections of Bill Cosby recordings.

\section{Procedure and Design}

Phase 1: Escape Pretraining. Ss were assigned randomly to one of three groups receiving 0,15 , or 30 cue-correlated trials (E0, E15, and E30, respectively). Each of the three groups consisted of 10 male and 14 female Ss. Ss in Groups E15 and E30 were given the following instructions: "You will be listening to some Bill Cosby recordings. From time to time the sound will go off. You may or you may not be able to prevent the recording from going off." Following these instructions, Ss received the escape trials. The warning signal was presented for $3 \mathrm{sec}$ immediately prior to recording offset. The maximum recording omission interval was $10 \mathrm{sec}$. A response to the light immediately terminated the light but did not prevent the occurrence of the omission interval. An escape response during the omission interval immediately reinstated the recording and initiated a 10 -sec intertrial interval in which the recording played continuously. For Ss in Group E15, an escape criterion of 13 of 15 escape responses within 40 trials was adopted. An escape criterion of 27 of 30 escape responses within 55 trials was established for Ss in Group E30. Ss in Group E0 were placed immediately in Phase 2.

Phase 2: Inescapable Trials. One-half of Ss in each of the three escapable pretraining groups were assigned randomly to groups receiving either 0 or 100 inescapable trials (I0 and I100, respectively). Each of the six subgroups consisted of five male and seven female Ss. Ss in Group E0 receiving 100 inescapable trials received the same instructions as did Ss in Phase 1. Ss in Groups E15 and E30 receiving 100 inescapable trials were given no further instructions regarding Phase 2 which followed immediately after Ss reached the appropriate escape criterion for Phase 1. For the inescapable trials, the intervals remained the same as in Phase 1. A response to the light immediately terminated it. However, an escape response did not reinstate the recording. The recorded material was reinstated only after the maximum $10-\mathrm{sec}$ omission interval had elapsed. During the 10 -sec intertrial interval, the recording played continuously. Ss in Groups E15 and E30 not receiving inescapable trials were given the escape/avoidance trials immediately after reaching their escape criterion in Phase 1.

Phase 3: Escape/Avoidance Trials. Ss in Group E0 not receiving inescapable trials were given the same instructions as the other Ss. In Phase 3, all 72 Ss were given 40 avoidance conditioning trials. For these trials a response during the 3 -sec warning signal duration immediately terminated the light and initiated the 10 -sec intertrial interval, thereby preventing the occurrence of the recording omission interval. An escape response during the maximum 10 -sec recording omission interval immediately reinstated the recording and initiated the $10-\mathrm{sec}$ intertrial interval.

\section{RESULTS}

The dependent measure employed in Phase 2 was the number of nonresponses made by Ss in Groups E0, E15, and E30 for the 100 inescapable trials. The trials were divided into five blocks of 20 trials each. The S's scores on each block were subjected to a $\sqrt{\mathrm{X}+1}$ transformation to reduce heterogeneity of variance. A 3 by 5 repeated measures analysis of variance (Winer, 1971) was performed on the transformed scores. The escapable trials pretraining main effect for Phase 1 was not significant $(F<1)$. The within-Ss trial block main effect was significant $(\mathrm{F}=11.19, \mathrm{df}=4,132, \mathrm{p}<.01)$. A Tukey (a) post hoc comparison test (Winer, 1971) performed on the trial blocks main effect indicated that (a) Ss had significantly more nonresponses over the last four trial blocks than on Trial Block $1(\mathrm{p}<.01)$ and (b) Ss had significantly more nonresponses in Trial Blocks 4 and 5 than in Trial Blocks 2 and $3(p<.01)$.

The dependent measures in Phase 3 consisted of the number of (a) nonresponses, (b) escape responses, and (c) avoidance responses made by Ss across the 40 trials. The escape/avoidance trials were divided into four blocks of 10 trials each. Scores on each dependent measure were subjected to a $\sqrt{\mathrm{X}+1}$ transformation and are presented in Table 1.

A 3 by 2 by 4 repeated measures analysis of variance (Winer, 1971) was performed on the number of nonresponses. The between-Ss inescapable trials main effect was significant $(\mathrm{F}=50.86, \mathrm{df}=1,66, \mathrm{p}<.001)$. The within-Ss main effect for trial blocks $(F=14.50, \mathrm{df}$ $=3,98, p<.001)$ and the Inescapable Trials by Trial Blocks interaction $(F=9.55, \mathrm{df}=3,98, \mathrm{p}<.001)$ was significant. A Tukey (a) comparison test performed on this interaction indicated that (a) at each successive trial block, Ss receiving the inescapable trials had significantly fewer nonresponses $(p<.01)$ and (b) Ss given inescapable trials had significantly more nonresponses in each of the four trial blocks than did Ss not given inescapable trials $(\mathrm{p}<.01)$.

A similar 3 by 2 by 4 analysis of variance was performed on the number of escape responses. A significant between-Ss main effect for the escapable pretraining condition was obtained $(\mathrm{F}=5.40, \mathrm{df}=2,66$, $\mathrm{p}<.01$ ). A Tukey (a) post hoc test indicated that each escapable group differed significantly from each other $(p<.01)$. The between-Ss inescapable trials main effect $(\mathrm{F}=30.34, \mathrm{df}=1,66, \mathrm{p}<.001)$ and the Inescapable Trials by Trial Blocks interaction $(\mathrm{F}=7.39, \mathrm{df}=3,198$, $\mathrm{p}<.001$ ) were significant. A Tukey (a) test performed on this interaction indicated that (a) Ss given inescapable trials made significantly more escape responses across the last three trial blocks than in Trial Block $1(\mathrm{p}<.01)$ and (b) on each trial block, Ss receiving inescapable trials made significantly fewer escape responses than did Ss not given inescapable trials $(\mathrm{p}<.01)$.

A third 3 by 2 by 4 analysis of variance performed on the avoidance response measure yielded a significant within-Ss main effect for trial blocks $(\mathrm{F}=9.45 \mathrm{df}=$ $3,198, \mathrm{p}<.001$ ). A Tukey (a) test indicated that (a) Ss made significantly more avoidance responses across the last three trial blocks than in Trial Block $1(\mathrm{p}<.01)$ and (b) significantly more avoidance responses were made in Trial Block 4 than in the first three trial blocks $(\mathrm{p}<.01)$.

\section{DISCUSSION}

The present results confirmed the hypothesis that successful escape/avoidance performance in human Ss using omission of entertaining material as the aversive stimulus event would be interfered with by prior experience with inescapable 
presentations of the aversive event. Analysis of the nonresponses in Phase 2 indicated that 15 or 30 prior escapable trials did not differentially affect the number of nonresponses made.

The separate nonresponse, escape, and avoidance analyses for groups in Phase 3 are not independent; however, they provide for a clearer indication of the precise effects of the escapable and/or inescapable treatments on escape/avoidance performance. The nonresponse analyses indicated the interference effect. The number of nonresponses decreased significantly across the 40 escape/avoidance trials for Ss receiving the inescapable trials. However, Ss not presented the inescapable trials were making significantly more responses than were Ss receiving the inescapable trials.

The number of escapable trials Ss received in Phase 1 facilitated acquisition of escape responses in Phase 3. Ss not given escapable pretraining made significantly fewer escape responses than Ss receiving escapable pretraining. Ss receiving 30 escapable trials made significantly more escape responses than did Ss receiving only 15 trials. The interference effect of inescapable trials was also evident. While Ss receiving 100 inescapable trials made significantly more escape responses over the last three trial blocks than on the first trial block, these Ss made significantly fewer escape responses across all four trial blocks than did Ss not receiving the inescapable trials.

Avoidance responding was relatively insensitive to the independent variables employed. Although Ss made significantly more avoidance responses over the last three trial blocks than on the first trial block, these responses were independent of prior escapable and/or inescapable trials.

Seligman et al (1971) described the learned helplessness paradigm as an independent, noncontingent relationship between $S$ 's responses or nonresponses and reinforcement. It is the uncontrollability of a specified response to affect change in the probability of reinforcement occurring and not the particular aversive stimulus employed that defines the concept. Ss can learn they have no control over the occurrence of reinforcement whether it be in terms of cessation of shock or reinstatement of entertaining recordings. The degree to which this interference effect was negated was shown in the present experiment to be directly related to the amount of control Ss had over the aversive event.

The use of omission of entertaining material as an aversive event minimizes the instructional set which Thornton and Jacobs (1971) cited as one potential source of their discrepant results. They did not find any interference effect when Ss were allowed to set their own fixed shock level. This failure was attributed to the intensity of shock reported as unpleasant but not painful by
Table 1

Mean Number $(\sqrt{\mathrm{X}+1})$ of Nonresponses (NR), Escape (ER), and Avoidance (AR) Responses Across Trial Blocks in Phase 3

\begin{tabular}{|c|c|c|c|c|c|c|c|}
\hline \multirow{3}{*}{$\begin{array}{c}\text { Depen- } \\
\text { dent } \\
\text { Mea- } \\
\text { sures }\end{array}$} & \multirow{3}{*}{$\begin{array}{c}\text { Trial } \\
\text { Blocks }\end{array}$} & \multicolumn{6}{|c|}{ Phase 3 Escape/Avoidance Groups } \\
\hline & & \multicolumn{3}{|c|}{10} & \multicolumn{3}{|c|}{$\mathrm{I} 100$} \\
\hline & & E0 & E15 & E30 & E0 & E15 & E30 \\
\hline \multirow{4}{*}{ NR } & 1 & 1.26 & 1.00 & 1.03 & 2.22 & 2.47 & 2.21 \\
\hline & 2 & 1.00 & 1.00 & 1.06 & 2.12 & 2.04 & 1.95 \\
\hline & 3 & 1.03 & 1.00 & 1.00 & 1.94 & 1.83 & 1.66 \\
\hline & 4 & 1.00 & 1.00 & 1.06 & 1.75 & 1.61 & 1.42 \\
\hline \multirow{4}{*}{ ER } & 1 & 2.61 & 2.60 & 3.22 & 1.34 & 1.39 & 1.68 \\
\hline & 2 & 2.15 & 2.68 & 3.00 & 1.14 & 1.61 & 1.89 \\
\hline & 3 & 2.26 & 2.57 & 3.03 & 1.17 & 1.80 & 2.10 \\
\hline & 4 & 2.14 & 2.35 & 2.79 & 1.25 & 1.90 & 2.20 \\
\hline \multirow{4}{*}{$\mathrm{AR}$} & 1 & 1.73 & 1.87 & 1.17 & 1.91 & 1.70 & 1.87 \\
\hline & 2 & 2.29 & 1.76 & 1.43 & 2.13 & 1.89 & 1.64 \\
\hline & 3 & 2.24 & 1.89 & 1.40 & 2.34 & 1.84 & 1.67 \\
\hline & 4 & 2.27 & 2.09 & 1.68 & 2.43 & 1.90 & 1.90 \\
\hline
\end{tabular}

Ss. The present results question the necessity of employing physically aversive stimuli to produce this interference effect.

Future research concentrating on the precise experimental conditions which influence the establishment, permanence, and elimination of the learned helplessness in human Ss is necessary, and, for humane considerations, the present type of aversive stimulus event offers promise for such research.

\section{REFERENCES}

Koch, D. L., \& Moffat, G. H. Effect of type of aversive event and warning signal duration on human avoidance performance. Bulletin of the Psychonomic Society, 1974, 5, 285-288.

Seligman, M. E. P., \& Maier, S. F. Failure to escape traumatic shock. Journal of Experimental Psychology, 1967, 74, 1-9.

Seligman, M. E. P., Maier, S. F., \& Solom on, R. L. Unpredictable and uncontrollable events. In F. R. Brush (Ed.), Aversive conditioning and learning. New York: Academic Press, 1971.

Thornton, J. W., \& Jacobs, P. D. Learned helplessness in human subjects. Journal of Experimental Psychology, 1971, 87,
367-372.

Winer, B. J. Statistical principles in experimental designs. (2nd ed.) New York: McGraw-Hill, 1971.

(Received for publication May 28, 1974.) 